\title{
Multiliteracy in The Rite of Grebeg Pancasila as aMedium for Character Education in Digital Era
}

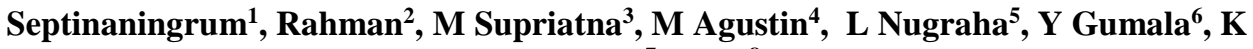 \\ Wachidah $^{7}$, Opik $^{8}$ \\ $\left\{{ }^{1}\right.$ ningrumseptina@gmail.com, ${ }^{2}$ rahmanprofupi@upi.edu, ${ }^{3}$ ma2t.supri@upi.edu, \\ ${ }^{4}$ mubiar@upi.edu, ${ }^{5}$ lukmanmifdha82@gmail.com, ${ }^{6}$ yosigumala@ @student.upi.edu, \\ ${ }^{7}$ kemilwachidah@umsida.ac.id, ${ }^{8}$ gerimisculamega@yahoo.co.id \} \\ ${ }^{1}$ IAIN Tulungagung, Indonesia \\ ${ }^{2,3,4}$ Universitas Pendidikan Indonesia Bandung, Indonesia \\ ${ }^{5}$ STAI Miftahul Huda Subang, Indonesia \\ ${ }^{6}$ Universitas Bhayangkara Jakarta Raya, Indonesia \\ ${ }^{7}$ Universitas Muhammadiyah Sidoarjo, Indonesia \\ ${ }^{8}$ SDN 2 Cikuya Culamega, Indonesia
}

\begin{abstract}
Indonesia with a variety of tribes and cultural diversity also has a variety of traditional ceremonial rites. The city of Blitar as part of this country also has various rites, one of which is Grebeg Pancasila. The purpose of this research is to describe multiliteration in the Grebeg Pancasila rite in order to preserve the history of the birth of the Pancasila. The approach and type of research used in this study is descriptive qualitative with the library research method (library research). Multiliteration which is examined in the Grebeg Pancasila rite includes religion literacy, cultural literacy, human literacy, beauty literacy, media and technology literacy, number literacy, economic literacy, reading literacy, communication literacy and others. This is an action taken to commemorate and preserve the spirit of struggle in upholding Pancasila as the philosophy of life of the Indonesian people.
\end{abstract}

Keywords: The Rite of Grebeg Pancasila, Multiliteracy

\section{INTRODUCTION}

There are many countries in the World. Each country has rituals or traditional ceremony consisting of meanings and multiliteracy which are the unique characteristics of people culture at the nation. City of Blitar, as a part of the nation, has various rituals; one of them is Grebeg Pancasila.

Grebeg Pancasila was firstly held in 2000 exactly at The City Blitar. In every ritual, they perform with a touch of ethnical tools and aesthetics integrated with symbols of Javanese Culture. Those symbols are implied and full of meanings with traditional values of Indonesian cultural that need conservation. As we know, today, globalization has threatened the existence of nation's cultural and ethical values. Dynamic era has contributed to send Indonesia to digital era. This era of digital is signified by rapid development of technology so that information's can be accessed easily. This has caused degradation to the character coming from nation's 
culture itself. People seem to be more comfortable with foreign cultures than local cultures. Consequently, the people character in Indonesia gradually degradated.

There is a gap between reality and observation. In fact, character building administered by the government though the Decree of Education and Culture Minister Number 20 in 2018 on Optimization of Character Building in formal education has not been effective yet. Ideally, students should be able to perform 18 characters effectively based on local characters in Indonesia. The cultural values of the nation are degradated by foreign cultures which can be freely accessed and adopted by students in Indonesia.

The 18 characters of national education are not reflected in the students' mind, speech and behaviour. Based on the KPAI (Indonesiancommission of child protection), the data is really apprehensive. KPAI has handled 1,885 cases in the first semester of 2018. From those cases, drug abuse, theft, and sex abuse become the most faces cases by the children. Data from KPAI showed there are 504 cases where the children deal with the law directly. The alternative parenting and family become the second most concerned case by children, there are 325 divorcement cases. Then sex abuse, pornography and cybercrime become the third most concerned case. Those facts show that the rapid development of technology contribute to the national morality degradation. School only teach basic literacy such as reading, writing, and counting as basically literacy. This is considered not sufficient to be taught in digital era with various modern technologies so that character and culture are neglected. In fact, culture, ethnicity is a national asset that must be preserved. Culture serves as a counterweight to the development of times in this digital era so that people do not forget their ethnic culture and national identity[1].

Culture has been a reflection of civilization in a country. Basic thought of digital era and history deals with the concept of multiliteracy related to multi-context, multimedia, and multicultural[2]. Multiliteracy is the development of literacy concepts where learning integrating learning of reading skill, writing skill, and speaking skill. Therefore, skilled must be mastered for multiliteracy learning are advanced reading skill, proficient writing skill, and speaking skill[3][4][5][6]. Ideally, multiliteracy and internalization of education can be implemented through education culture.

The rite of Grebeg Pancasila, as one of cultural heritage of Indonesia, can be used as an alternative solution for the problems above. As a cultural attraction, rite held to commemorate Pancasila Day, is considered full of character education included in religion, Pancasila, culture, and national education goals in this digital era.

\section{RESEARCH METHOD}

Research design applied was descriptive research with qualitative approach. The researcher applied library research method. There are three research instruments used to collect the data; interview, library study, and documentation. The qualitative research procedure using grounded theory method consists of several stages: (1) problem formulation, (2) using theoretical studies (if necessary), (3) data collection and delivery, (4) analysis stage, and (5) inference or report writing[7]. 


\section{RESULT AND DISCUSSION}

\subsection{Profile of Grebeg Pancasila}

According to ancient Javanese dictionary, grebeg can be defined as thundering amount of footsteps. Historically, grebeg is derived from the word gumbrebeg which means noisy, loud, and crowded. Those words describe grebeg as noisy, loud and crowded. Grebeg is also define as rumbling wind. In Javanese, anggarebeg is defined as escorting the king, public figure or bride. However, in Surakarta and Yogyakarta, garebeg has special meaning such as the kingdom ceremony held to commemorate the birth of the Prophet Muhammad SAW and to celebrate Aid Mubarak and other Islamic feast days[8].

Whereas, in the City of Blitar, grebeghas a meaning to get closer and to pray to Almighty God so that they will be given salvation and prosperity. It is also held annually on the first day of June. It is held to conserve the nation's glorious values such as to celebrate anniversary of Pancasila as the nation's glorious cultural values.

Historically, Pancasila was the result of Soekarno's reflection about Indonesia delivered at the $1^{\text {st }}$ of June 19945 in the convention of BPUPKI (a body of initiative investigation for Indonesia Independence Arrangements) and was named as Pancasila. Pancasila was approve by the constitution on August 18, 1945 as the basis of the state, a view of life, a national ideology, and a ligature (univer) o the nation and state of Indonesia [9]. The arise of Pancasila has become national convention, especially since the Information Ministry in 1947 published Soekarno's speech in form of book entitled Lahirnya Pancasila.

Tempo Magazine June 1, 2018 edition provides information that In the new order regime, the commemoration of Pancasila was not held and resonated anymore. Since 1970, KOPKAMTIB (Commando for Security and Discipline) disallowed the commemoration of Pancasila. After eight years of being banned on June 1, it can be celebrated as the day of the birth of Pancasila trough a session in the Political and Security Council led by the Coordinating Minister for Politics and Security, Gen. M. Panggabean. The anniversary of the Pancasila on June, 1978 was held at the Jakarta National Awakening Building. After the reformation era, people's consciousness on commemorating Pancasila did not arise. At last, diappointment and anxiety appears from artists and culturalists. Finally, Grebek Pancasila was conceived by Mr. Agus Putu Parto and being realized in 2000 [10].

According to Mr. Djoko Harjianto Nagoro, as the Head of Art and Culture Deputy and the committee of Grebeg Pancasila was firstly held in 2000 in The City of Blitar. Grebeg Pancasila was firstly held in Gebang Palace. The basic concept of Grebeg Pancasilaconsists of three rituals. The first is cultural ceremony, the second is Gunungan Lima flutter, and the third is Pancasila Feast. In every procession, touch of ethics and aesthetics ware presented integrated with Javanese cultural symbols. Those symbols are implicit, however full of meaning consisting of cultural eminent values. Grebeg Pancasila, as a tradition consisting of symbolic interaction, is important to understand the values on it. Moreover, it is important to take care and to conserve culture with meanings and values on it so that the values and meanings are not be eroded and neglected because of foreign cultures.

The basic law of Grebeg Pancasila is the Mayor Decree Number 34 in 2004 about the work procedure in information, communication and tourism bureau of Blitar and the seminar result of grebeg standardization in April 22, 2004. The seminar is held to optimize tourism attraction of Grebeg Pancasila Ritual[11]. The ritestandardization developed to be five prosession; Bedhol Pusaka Grebeg, Malam Tirakatan, Upacara Budaya,KirabGunungan Lima, and Kenduri Pancasila. 


\subsection{Grebeg Pancasila Analysis Based on Multiliteracy and Culture}

The campaign of school literacy has actually been started by the Ministry of Education and Culture in 2015. This program was expected to improve the quality of human resources through culture of understanding information critically, analytically, and reflectively[12][13]. This campaign is implemented as an effort to grow spirit of reading among the students especially middle high school students. Literacy is understood as an ability to access, understand, and use something smart through a variety of activities such as reading, observing, paying attention, writing and speaking.

Multiliteracy investigated in Grebeg Pancasilariteare religious literacy, cultural literacy, human being literacy, beauty literacy, media and technology literacy, numeric literacy, economic literacy, reading literacy, science literacy, communication literacy and so on.

Literacy of religion, in Grebeg Pancasila ritual, includes the development of spiritevalues. At the riteof Tiratakan Lima night, Pusaka Nagari is placed side by side with riteserving consisting of buceng kerep, a bunch of banana, coconut fruit, some snacks and candles. The smoke coming from the candle fills the room and get the room more sacred until morning[10]. The use of riteserving is identical to Budhism and Hinduism. While the use of candle is identical to Christianity.

Whereas, the literacy of religion can also be seen in the last ritewhich is the closing ceremonial sequences by performing Feast Pancasila preceded by an opening speech from the keeper of keys of Soekarno's tomb. After that, they pray together before they have traditional food consisting of yellow rice and some fish or meat. The prayer in this riteis conducted based on Islam.

Cultural literacy or local wisdom is a very important thing for a country. Culture is a unique characteristic of a country so it is different from the others. Culture is defined differently in various ways. Narito formulates local wisdom as the knowledge that discovered or acquired by lokal people through the accumulation of experiences in trials and integrated with the understanding of surrounding nature and culture. Local wisdom is dynamic by function of created local wisdom and connected to the global situation[14].

There are some concepts of local wisdom; (1) local wisdom is a long experience, deposited, to reflect someone's behaviour; (2) local wisdom cannot be separated from the surroundings environment; (3) local wisdom is dynamical, flexible, open, and adaptive to the recent situation of life. Those concepts expresses that local wisdom is always related to our life and our environment. Local wisdom appears to filter global climate colliding with human life.

After analyzing Grebeg Pancasila based on the concepts above, the researcher states that; (1) Grebeg Pancasila is a long way experience of the society in Blitar City concerning and be critical to know about the degradation of nationalism towards the Pancasila Day (2) Original Grebeg Pancasila, appears, grew, and developed in Blitar for the first time. (3) Grebeg Pancasila is a local wisdom which is dynamic, flexible, open, and adaptive the current era by considering the the essence of the core procession and ritual.

In accordance to the human literacy, Emy Hudayanti (2018) states that the event of Grebeg Pancasila is joint by all level of people such as civil servant, culturists, artists, entrepreneurs, traders, or students and society[11]. The involvement of all circles shows a high spirit of nationalism towards the rite of Grebeg Pancasila.

Literacy of Beauty is held and joint by all level of people in the City of Blitar. There are audiences also come from overseas to enliven this ritual. If the audiences want to participate in 
the riteof Grebeg Pancasila, they must wear traditional clothes of East Java. Men must wear black jacket with a chain circled on their chest, the trousers is covered by cloth and they must wear blangkon (javanese traditional hat). Woman must wear kebaya and Jarit fabric with batik on it and women must wear hair bun or modified veil for moslems. Moreover, all participants must wear all traditional clothes from all over the country.

Media and technology literacy in the riteof Bedhol Pusaka Nagari where three relics of Nagari such as Indonesian Flag, the Text of Pancasila, speech from Soekarno, Garuda and the photo of Soekarno are stucked to the black board. All soldiers walk forward and get through the city which is crowded by the audiences accompanied by the melody of gamelan and various lampion festival till they reach the mayor office of Blitar for the next ritual. Media and technology literacy can be found at the audio media used and the lampion look like Pancasila with variety of color make the ritebrighter.That comprises multiple form of media and communication and emphasises cultural[15].

Numerical literacy ability is related to analytical thinking and correlates with reading ability so that is able to apply mathematical concepts and rules to solve problems in daily life[3][12]. Numeracy literacy besides being reflected in lampion festival where the participants must queu to get the number can be seen in the riteof Bedhol Pusaka Nagari. They are devided into soldier 1 , soldier 6 and soldier 45. That means that every soldier group consists of 1, 6 and 45 soldiers. The number of 1, 6 and 45 is the birth day of Pancasila which is June $1,1945$.

Economic Literacy can be seen when they buy furniture or goods as the social activity on Economy. From Bedhol Pusaka Nagari, lampion festival needs various stuff and equipments to create lampion. The night riteof Tirakatan Lima Pusaka Nagari needs various riteservings consisting of buceng kerep, a bunch of banana, coconut fruit, snacks and candles.

Cultural ceremony on the 1 st of June in the morning at Blitar square use gamelan to be mixed with the song of Gending Bumi Pertiwi created by Ki Narto Sabdo. Moreover, Gunungan Lima Carnival is paraded by the soldiers followed by hundreds of other participants. Each component consists of the heart of banana flower, chillies, oranges, carrots, unions, garlic, longbeans. Each component has its in depth own meaning and various cones in Pancasila festivity.

In reading literacy, there are three different meanings when reading; literal meaning, inferential meaning, and personal meaning[16]. They develop understanding that reading competence has previously a very important meaning in maintaining the meaning and some meanings surrounding the text. This kind of literacy appears in all rituals of Grebeg Pancasila.

Communication literacy, communication is a skill to share thought, question, ideas, and solution to solve problems. Communication consists of several kinds involving communication through oral communication, written communication, auditory communication, visual communication or digital communication[17]. It can be seen that there are various ritein Grebeg Pancasila. People can see oral communication by using temabang Mocopatan Banjaran Bung Karno at the night riteof tirakatan and the reading of Pancasila text at the cultural ritual. Writen communication can be found in brochure and advertisement board. Auditory, visual, and digital communication can be found at Lampion Festival of Bedhol Pusaka Nagari, Cultural Ceremony, Gunungan Limo Carnival and Pancasila Feast. 


\subsection{The Implementation of Multiliteracy in Grebeg Pancasila Riteas A Medium of Character Education in Digital Era}

Multiliteracy is known as a new paradigm in literacy learning. Communication literacy, communication is a skill to share thought, question, ideas, and solution to solve problems. Communication consists of several kinds involving communication through oral communication, written communication, auditory communication, visual communication or digital communication. It can be seen that there are various ritein Grebeg Pancasila. It can be authentic experience for some student and teacher. The authentic experiences of interacting with others in different aspect of their undergraduate studies, such as organising Student Union activities and joining overseas trips[18].In Grebeg Pancasila student and teacher can see oral communication by using temabang Mocopatan Banjaran Bung Karno at the night riteof tirakatan and the reading of Pancasila text at the cultural ritual. Writen communication can be found in brochure and advertisement board. Auditory, visual, and digital communication can be found at Lampion Festival of Bedhol Pusaka Nagari, Cultural Ceremony, Gunungan Limo Carnival and Pancasila Feast.

Multiliteracy is known as new paradigm in literacy learning. The learning implication of literacy contributes to the appearance of new concept of multiliteracy. The concept of multiliteracy appears because people do not just read or write, but they read and write special genres involving social goal, culture, politics which are the demand of digital era. So, this has been the foundation of the multiliteracy in education. Character has become an important issue recently. Character internalization in Grebeg Pancasila ritethat can be seen is religion and nationalism. Religious character can be seen in Riteof Tirakatan night and the prayer of Pancasila Feast Ritual.

The criteria of nationalism according to Agustarini in Rifa'I et al, consist of (1) protecting and taking care the nation, (2) sacrificing and patriotism (3) United Indonesia (4) conserving Indonesian cultures (5) love the homeland, (6) proud to be Indonesian, (7) paying tribute to humanity[19]. In Grebeg Pancasila ritual, those characters are seen in every procession. Grebeg Bedholan, Night of Tirakatan, Cultural Ceremony, Gunung Lima Carnival, and Pancasila Feast.

The analysis of Pancasila based on the nationalism criterion above such as; (1) protecting the nation including in every procession, (2) sacrificing trait character and patriotism reflected when they are willing to participate in every activity through efforts by spending money, sacrificing their time or their other necessity, (3) United Indonesia is actualized in the unity of all people in Blitar when participating in the riteprocession (4) conserving Indonesian cultures is seen in Bedholan Grebeg and Gunungan Limo Carnival or Cultural Carnival, (5) Homeland love can be seen in procession of Cultural ceremony where the flag of Indonesia waving and the national anthem of Indonesia sung, (6) Being proud to be Indonesian through the cultural ceremony and Gunungan Limo carnival, there are various culture of Indonesia, (7) paying tribute to humanity through religious activities by praying as thanks giving to Allah SWT in the Tirakatan Night procession. The Pancasila Carnival is a medium of fellowship among the society and sharing sustenance. Those activities are the humanity activities because all become united without any gap of difference [20]. All are dissolved in activities without any caste differences, without any difference between the poor and the rich. 


\section{CONCLUSIONS}

The study and analysis has proven that multiliteracy, religious character and nationalism are reflected in every procession in Grebeg Pancasila ritesuch as Bedholan Grebeg, Tirakatan Night, Cultural Ceremony, Gunung Lima Carnival, and Pancasila Feast. Those five precessions contain meaning that must be kept and conserved. The variety of art and culture can be used to deliver the message of nationalism values and character.

The relationship between Grebeg Pancasila and education in Indonesia by bringing forward the character building especially nationalism so the students love the variety as contained in Pancasila which is the life philosophy of Indonesia must be respected by all citizens of Indonesia. This riteis also the medium of education about the slogan written in Pancasila which is "Bhinneka Tunggal Ika" (pluralism in unity) where in every procession of the riteis enlivened by the various cultural performances such as dance, local art and music, traditional clothes, traditional food, and etc. Those can be used as media of learning for unity in pluralism.

\section{REFERENCES}

[1] R. Rahman, A. W. Sakti, R. N. Widya, and R. Yugafiati, "Elementary Education Literacy in the Era of Industrial Revolution 4.0," vol. 257, no. Icollite 2018, pp. 190193, 2019.

[2] E. Untari, "Pertingnya Pembelajaran Multiliterasi untuk mhasiswa Pendidikan Guru Sekolah Dasar dalam Mempersiapkan Diri Menghadapi Kurikulum 2013," Wahana Sekol. Dasar (Kajian Teor. dan Prakt. Pendidikan), vol. 25, no. 1, pp. 16-22, 2017.

[3] Rahman, Kecakapan Literasi Sekolah Dasar. UPI Bandung, 2018.

[4] Rahman, Multiliterasi dan Pendidikan Karakter. UPI Bandung, 2018.

[5] D. Yayli, "New roles for literacy teachers in the age of multiliteracies: A sociocultural perspective," Procedia - Soc. Behav. Sci., vol. 1, no. 1, pp. 206-209, 2009.

[6] D. Kern et al., "Preparing reading/literacy specialists to meet changes and challenges: International Literacy Association's Standards 2017," Lit. Res. Instr., vol. 57, no. 3, pp. 209-231, 2018.

[7] I Gusti Ayu Nyoman Budiasih, "Metode Grounded Theory Dalam Riset Kualitatif," J. Ilm. Akunt. dan Bisnis, vol. 9, no. 1, pp. 19-27, 2014.

[8] M. Hanif and Z. Zulianti, "Simbolisme Grebeg Suro Di Kabupaten Ponorogo," Agastya J. Sej. Dan Pembelajarannya, vol. 2, no. 1, pp. 36-51, 2018.

[9] Luh Suryatni, "Komunikasi Media Sosial Dan Nilai-Nilai Budaya Pancasila Social Media Communications And Cultural Values Of Pancasila," J. Sist. Inf. Univ. Suryadarma, vol. 5, no. 1, pp. 117-133, 2018.

[10] D. Kepercayaan, T. Tuhan, Y. M. E. Dan, D. J. Kebudayaan, K. Pendidikan, and D. A. N. Kebudayaan, Seri Pengenalan Budaya Nusantara Grebeg Pancasila Perayaan Kelahiran Pancasila. 2016.

[11] Emy Hudayanti, "Strategi Optimalisasi Grebeg Pancasila Sebagai Wisata Budaya," Tour. Hosp. Culin. J., vol. 3, no. 1, pp. 44-58, 2018.

[12] D. R. Faizah, D.U., Sufyadi, S., Anggraini, L., Waluyo, Dewayanti, S., Muldian, W., Roosaria, Panduan gerakan literasi sekolah di sekolah dasar. 2016.

[13] A. L. Consalvo and A. D. David, "Writing on the walls: Supporting 21st century thinking in the material classroom," Teach. Teach. Educ., vol. 60, pp. 54-65, 2016.

[14] Wagiran, "Pengembangan Model Pendidikan Kearifan Lokal Dalam Mendukung Visi 
Pembangunan Provinsi Daerah Istimewa Yogyakarta 2020 (Tahun Kedua),” J. Penelit. Dan Pengemb. N, vol. 3, no. 5, pp. 1-29, 2011.

[15] K. Buckley-Walker, J. Tognolini, L. Lockyer, I. Brown, and P. Caputi, "Evaluating the validity of the online multiliteracy assessment tool," Aust. J. Educ., vol. 61, no. 3, pp. 305-327, 2017.

[16] Ryan Dwi Puspita \& Rahman, "Meningkatkan Kemampuan Membaca Pemahaman Berbantuan Pembelajaran Tematik Terpadu Bernuansa Model InteractiveCompensatory," Pendas Jurna Ilm. Pendidik. Dasar Unpas, vol. II, no. 2, pp. 200 211, 2017.

[17] Rahman, Media Audio Visual sebagai Penunjang Pembelajaran dalam Konteks Keterampilan Abad 21, no. c. UPI Bandung, 2018.

[18] S. Y. F. Tang, M. M. H. Cheng, and A. K. Y. Wong, "The preparation of pre-service student teachers' competence to work in schools," J. Educ. Teach., vol. 42, no. 2, pp. 149-162, 2016.

[19] A. Rifa'i, S. D. WP, and M. Y. Alimi2, "Pembentukan Karakter Nasionalisme melalui Pembelajaran Pendidikan Aswaja pada Siswa Madrasah Aliyah Al Asror Semarang," J. Educ. Soc. Stud., vol. 6, no. 1, pp. 7-19, 2017.

[20] B.W. Setyawan and K. Saddhono, "Eret traditional ceremony as representation of spirit of mutual cooperation among coastal communities”. Adv. Sci. Let. vol. 23 no.10, pp 9991-9992, 2017 